JELTL (Journal of English Language Teaching and Linguistics)

e-ISSN: 2502-6062, p-ISSN: 2503-1848

2020, Vol. 5(3)

www.jeltl.org

\title{
Attitude towards Javanese Language: A Case Study of English Department Students in Brawijaya University, Indonesia
}

\author{
Destyana Cory Prastiti \\ Brawijaya University, Indonesia \\ Email: destyanacp@gmail.com \\ Emy Sudarwati \\ Brawijaya University, Indonesia \\ Email: emoy_sanyoto@ub.ac.id
}

\begin{abstract}
This study aims to scrutinize the attitude of Javanese youth towards their use of local language. There are two research questions proposed in this study such as namely: 1) how is the attitude of Javanese youth towards their local language, 2) what are the factors that effect on their attitudes. The objectives of this study are to define the attitude of Javanese youth towards their local language and to discover why they are behaving so. Furthermore, this study adopted qualitative method applying descriptive analysis and selected the students of English Department of Batch 2014 Batch in Brawijaya University as the participants. The results showed that the subjects indicated showed both positive and negative attitudes towards the use of Javanese language depending on the context. The positive attitude was frequently revealed on questions related to their efforts in conserving Javanese as the local language, while the negative attitude was mostly reflected on the statements associated with their language preference in daily life. Moreover, there are several factors affecting their language attitudes namely the Javanese language internal system, social and traditional, and the prestige and the power of language.
\end{abstract}

Keywords: Javanese youth, language attitude, local language 


\section{Destyana Cory Prastiti and Emy Sudarwati}

\section{INTRODUCTION}

A country can be home for many types of language, either national language or the local one. National language is the official language of the country and is widely spoken and used in writing by a majority of the population (Tamtomo, 2012, pp. 4). According to Tabi Manga (2000), national language is used in some parts of the world to refer to languages unique to the nation as distinguished from international languages, while local language refers to the language spoken in the homes and marketplaces of a community or particular ethnic group. These two kinds of language are commonly used in different states of condition. For example, local language tends to be used to communicate with people from the same ethnic, region and commonly used in the informal context, meanwhile the national language is mostly used to communicate with other people from diverse ethnic backgrounds.

In Indonesia, Javanese language is considered as one of local languages which have enormous native speakers, spoken by over 7 million people in the world (Subroto et al., 2008). However, the number of Javanese language native speakers can be decreased and its existence can be replaced by other languages in the future. There are some affecting factors one of which Some factors might affect, but one of them is it can be caused by language attitude which refers to the people's feelings, attitudes or believes about language in general, their language, and the language of other people.

Youth as part of Javanese society isare often at the cutting edge of multilingualism with their propensity to be agents of linguistic change, adopting new and hybrid language forms, and embracing new digital (Bucholtz \& Skapoulli, 2009; Rampton, 2005). Youth also have the tendency to use and mix various language varieties in their practices of identity construction (e.g. Bucholtz, 1999; Eckert, 2000; Bailey, 2001). On the other hand, they play important roles in preserving local language. Their attitudes or perceptions on Javanese language become more vital in determining whether local language will survive or die out in the future.

Issues on language attitude is still very quiet interesting to be investigated. Some language attitude studies are connected to the effort in maintaining the language of a community (Hartono, 2013; Machmud \& Hastuti, 2019; Nirmala, 2015; Wulandari, 2013). Other studies concernings with the language attitude in relation to speech level (Pohan \& Butarbutar, 2020); language attitude and language preference (Laila, 2013); language attitude toward another vernacular language (Rahmawati, 2013); language attitude in relation to one's bilingualism (Setiawan, 2013); language attitude in relation to language domain (Fitri, 2018); language attitude in relation to cross cultural marriage (Seli, 2020). This study tries to fill in the gap by putting more effort on scrutinizing youth's attitude on their local language in this case Javanese is taken into account. Furthermore, another conducted by Ting \& Puah (2011), who conducted a study to find the attitude of Hokkien speakers towards Hokkien and Mandarin in Malaysia. The novelty of this current research lies on its subject which take having English department students as the researchers feel so curious in finding out if the foreign language that those students have already mastered may affect their language attitude toward their local language (Javanese) vernacular (Javanese). Researching university students also means to investigate if students may have different 
language attitude toward Javanese language as they rarely use the language in educational setting.

Thus, the researcher focuses on investigating the attitude of students who have Javanese ethnic background in English Literature Study Program 2014 at Brawijaya University and any factors that effect on its affecting factors. Their attitude towards Javanese language plays a vital role since they have been dealing with multilingualism in complex way such as they have to learn English, Bahasa Indonesia and use their local language at the same time. The result of this study can be used to determine the next steps in maintaining and revitalizing Javanese as the local language in Indonesia.

Based on the mentioned background of study, the present study aims at investigating the youth's attitude towards their use of Javanese language and factors that effect on their language attitude.

\section{LITERATURE REVIEW}

\subsection{Language Attitude}

Language attitudes are the people's feeling about their own language or the languages of others (Crystal, 2008). Not only feelings, language attitudes can also be in the form of perceptions and actions towards language and people using them. Generally, two theoretical approaches regarding the study of language attitudes are differentiated. The first one is the behaviorist point of view which highlights how particular attitudes are studied by observing the responses to certain languages (Appel \& Muysken, 1987). Furthermore, the mentalist view tends to consider attitudes as an internal, mental state, which may give rise to certain forms of behavior. It is commonly described as 'an intervening variable between a stimulus affecting a person and that person's response' (Fasold, 1984, as cited in Appel \& Muysken, 1987).

An attitude towards particular language can be positive or negative. Both positive and negative feelings towards a language may indicate impressions of linguistic difficulty or simplicity, ease or difficulty in the learning process, its degree of importance, elegance, social status among society, and so on. Negative attitudes on particular language are commonly manifested by speakers, and a group of people who speak in minority language are being stigmatized, so that the speakers tend to feel ashamed of it. While positive attitudes can be defined as positive responses given by the speakers toward particular language, for example, in appreciating the use of particular language.

\subsection{Factors Affecting Language Attitude}

There are many factors influencing on people's attitude towards particular language. According to Jendra (2010: 109), it is stated that people's language attitude is mostly affected by several factors as follow:

The prestige and power of the language. In many countries, being passionate to learn foreign language has been commonly known. Some people assume that learning foreign language will automatically correlate with declining the loyalty of the learners towards their national language or the local one. However, scholars claim that the enthusiasm in learning foreign language is not always associated with a negative attitude towards the nationalism and cultural feeling of the learners. In addition, Jendra (2010) also mentioned an example 


\section{Destyana Cory Prastiti and Emy Sudarwati}

related to this point. In Japan, most children are given chance to learn English as foreign language. As a result, it is found out that they tend to have a great interest in Western culture as well as the language they study. However, they remain holding on a strong Japanese identity as their root.

Historical background of nations. This factor is related to the history of the nation itself, such as colonialism. Indonesia, as a country that has ever been was once colonialized by Netherland and Japan, might be easily affected by this factor (Jendra, 2010). Negative attitude towards Dutch and Japanese might be found among Indonesian people due to their past experience as a colonialized country.

The social and traditional factors. In the society where diglossic situation is generally found, the higher variety of the language is normally thought as a better form than the lower one. In the society with a traditional polyglossia, a negative attitude may be expressed towards the use of higher language, especially if it is perceived as instrumental for controlling or downgrading the other people. Fasold (1984, as cited in Jendra, 2010) stated that where a society has linguistic varieties in diglossic relationship, the common attitude is that the high language is considered as better and purer language than the lower language.

The language internal system. Most people often show their positive attitude in the process of language learning because they think that its grammar, pronunciation, and vocabulary are relatively easy (Jendra, 2010). As the gender-based nominal system of the language is difficult to learn compared to English, many students might prefer to learn English, instead of French and German. The same case might be found in Indonesia, especially among Javanese speakers, where most children nowadays might show more positive attitude towards Bahasa Indonesia than Javanese language.

\section{RESEARCH METHODS}

This study adopted a qualitative method to scrutinize the attitude of Javanese youth towards their use of local language and the factors affecting on it. In line with Dornyei (2007), a qualitative research implicates data collection process resulting in open-ended, non-numerical data which is analyzed primarily by non-statistical method. In measuring language attitude, this study applied Fasold's theory (1984) which distinguished between direct and indirect methods. Direct method would require the participants to respond to a questionnaire or interview questions.

The participants consisted of 30 students of English Literature Study Program Batch 2014 in Brawijaya University who were randomly chosen. Their ages were ranging from 20 to 24 years old. They were in the 7 th semester and they had gained the capability to perform the required language skills well. The subjects had been dealing with multilingual condition for more than 2 years since the first semester. In addition, the participants also indicated Javanese ethnic background such as their parents from Javanese ethnic, born in East Java, Central Java, and Special Province of Yogyakarta and those who had been living in Javanese background area since they were toddler.

Questionnaires were used to answer the first research question related to the subject's language attitude. The items in the questionnaires developed from Nuryani (2014) and Setiawan (2013) were divided into two sections. In the first section, the subjects were 
required to answer some questions about their linguistics background information, while the second section consisted of two sets of questionnaires associated with their attitude towards Javanese language. The first set of questionnaires were designed based on Likert's four scales such as strongly agree, agree, disagree and strongly disagree. Neutral responses were eliminated from scales to simplify the subjects' attitude categorization. The second set of questionnaires was made up of a set of polar pairs of short statements regarding their beliefs. Their answers to the questionnaires allow some findings on their language attitudes towards Javanese as local language compared to other languages such as English and Bahasa Indonesia in terms of international and official language (Setiawan, 2013). Moreover, in order to investigate the factors which affecting on the subject's attitude towards Javanese language, some open-ended questions were given through the interview process. This instrument could help the subjects to elaborate their responses and opinions regarding their language use.

The qualitative data were derived from the 30 undergraduate questionnaires and interviews. The irrelevant data were eliminated, whereas the relevant ones were arranged to be further analyzed. The reduced data from the first set of questionnaires were analyzed using descriptive data analysis and classified into several categories namely language and lifestyle, language and impression for its speakers, language and its benefits, and language and its specific purposes according to Setiawan (2013). Later on, data gained from second set of questionnaires were categorized into two big groups based on the variables of findings and presented in charts. The first group was positive attitude and the second one was negative attitude towards Javanese as defined by Fasold (1984).

Furthermore, data from interview were analyzed by examining the reasons why the respondents showed such attitude in descriptive way without any subjective judgment. A content analysis method was applied and the researcher coded the themes manually as Dornyei (2007) explained this as themes or "qualitative categories" which inductively emerge when analyzing the data.

\section{FINDINGS}

The findings were presented based on the subjects' answers both from the questionnaires and interviews. These findings answered two research questions, they are; how is the Javanese youth's attitudes towards their local language and what are the factors affecting on their attitudes towards Javanese language.

\subsection{Subjects' Attitude towards Their Use of Local Language based on the Questionnaire Result (First Part)}

This part consisted of several pairs of short statements. Each of them represented the subjects' feelings, perceptions and opinions towards Javanese language. The analysis of data gained was presented in the following details.

\subsubsection{Language and lifestyle}

The first point was about language and lifestyle. It was represented by a pair of statement such as 'gaul' or 'tidak gaul'. In English, those words might have equivalent with 'cool' or 'uncool'. This term is used to ask the youth's opinion or feelings related to their pride in using Javanese language in their daily life. Smith-hefner (2007, as cited in Setiawan, 


\section{Destyana Cory Prastiti and Emy Sudarwati}

2013) explained that 'bahasa gaul' basically was social language or language of sociability. Furthermore, he also stated that the function of 'bahasa gaul' was to show solidarity among speakers and create new identity to differentiate between the youths and the older generation.

By knowing the function of 'bahasa gaul', the result indicated that the respondents wanted to show their solidarity among other Javanese speakers. However, there were 4 respondents claiming that Javanese language was 'uncool' and 1 respondent decided to leave the questionnaire blank. This result evidently can be caused by the feeling that Javanese language is not universal language, because it is only spoken by Javanese people. They thought that it did not help them socialize with other people from different ethnic or region. However, Javanese language was still preferred by the youth for their social life.

Another question related to language and lifestyle was whether Javanese language was considered as 'modern' or 'out of date'. Setiawan (2013) stated that this term is used with reference to someone who practices things no longer suitable with the present time. The result illustrated that there were 5 respondents who claimed Javanese language as a 'modern' or 'up to date' language, while there were 4 respondents who considered Javanese was 'out of date' language and 2 others decided not to answer. Those who agreed that Javanese language was 'up to date' was classified as positive attitude, while those who considered Javanese language 'out of date' can be was included to negative attitude.

\subsubsection{Language and impression for its speakers}

According to Setiawan (2013), Javanese people commonly use term 'ndesa' or 'ndesit' which has equivalent with 'village-like' to refer the condition of other people who are careless, uneducated, left behind, old-fashioned, under-developed, etc. In contrast, another opposite term of 'ndesit' was 'kutit = wong kuta' which has equivalent with 'urban-like'. Based on the result, there were 6 respondents saying that Javanese language conveyed 'village-like' conveyed to its speakers. It indicated that most of the respondents showed negative attitude. They thought that most people speaking Javanese were coming from 'under-developed' area.

The following question was correlated with the previous question. It was about whether the Javanese speakers were seen as 'rich' or 'poor' people. In community, the social gap between the poor and the rich one can could be observed easily. However, the subjects' responses showed contradictive result from the previous ones. Most respondents claimed that those who speak Javanese language were those considered as the 'rich' people.

\subsubsection{Language and its benefits}

Relating to this point, the highlighted term used was whether Javanese language could improve the speakers' confidence or not. Based on the questionnaire results, it showed 9 of 11 respondents were positive that Javanese language could make them feel more confident. It was because most of them thought that the more multilingual (more languages acquired) they are, the more confident they will be. However, the contrast result was depicted by 2 other respondents. They said that Javanese language did not make them feel more confident. 


\subsubsection{Language and its specific purposes}

Every language has its own advantages for the world, especially for the speakers. Related to Javanese language, the question was about its function for daily life. First term used was 'scientific' or 'not scientific'. Being asked about this, 8 of them agreed that Javanese language was not scientific. Most of them said that Javanese language cannot be used in academic life because it cannot be used to write kind of academic or scientific writing like journal, thesis and so on.

Further, respondents' attitude towards Javanese language were revealed when they were asked about regarding its function on in business and technology. Related to business, 9 of 11 respondents claimed that Javanese is not language for business, especially in the international level. While on in technology field, they also said that Javanese language is not appropriate to apply on this field. By this, it can be said inferred that most of the respondents showed negative attitude towards Javanese language and its relation to specific purposes.

\subsection{Subjects' Attitude towards Their Use of Local Language based on the Questionnaire Result (Second Part)}

The questionnaire on language attitude consisted of 10 questions to measure the respondents' attitude towards Javanese language. There were two intervals, categorized into positive and negative attitude. The positive attitude was measured by the number of responses on point 4 and 3 referring to 'strongly agree' and 'agree, while the negative attitude was based on responses on point 2 and 1 which refers to 'disagree' and 'strongly disagree' towards statements mentioned.

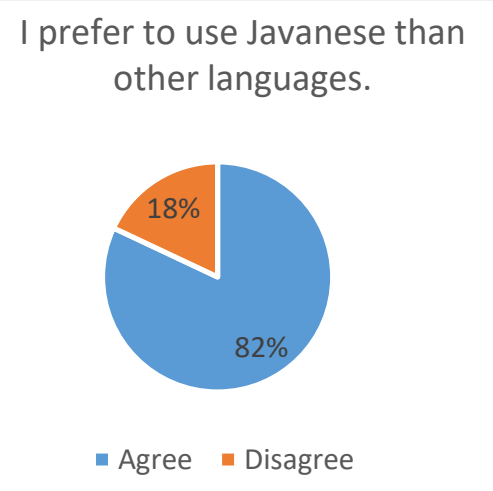

Figure 1 Subjects' responses on Javanese language preference

Question number one was about the respondents' attitude on their preference in using Javanese language for daily life. This question was typically used to measure the respondents' loyalty towards their use of local language.

There were 7 respondents who agreed, it indicated as a positive attitude towards the use of Javanese as local language. However, there were 4 respondents who disagreed, indicating their responses were negative attitude. Those who disagreed thought that it depended on the context and the addressee they talked to. Thus, they could not fully use Javanese language to communicate with others. After the interval was being calculated, 64\% respondents agreed to use Javanese in their daily life, and $36 \%$ respondents did not agree so. 


\section{Destyana Cory Prastiti and Emy Sudarwati}

This result indicated most of the respondents, as Javanese youths, still preferred to use Javanese as their daily language in any situation. Although some of them also said that it depended on the situation they faced.

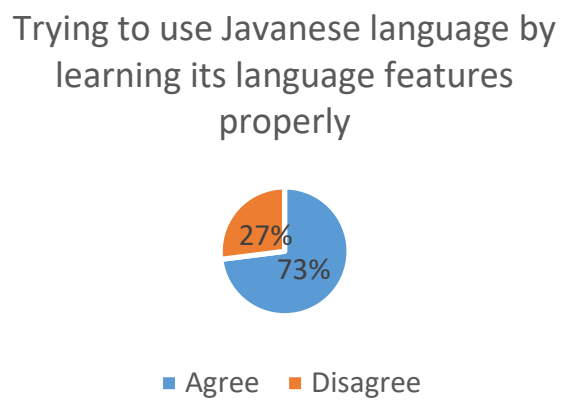

Figure 2 Subjects' responses on effort to learn Javanese language

Regarding Next, the second question concerns with $\mathrm{n}$, it was about the respondents' effort to learn more about Javanese language in order to use the language properly. This question was arranged to analyze the participants' awareness related to Javanese language rules. It was not only limited on the vocabularies and grammatical rules, but it was also referring to the Javanese language norm.

In total, there were 8 respondents agreed, which was included as positive attitude and 3 respondents left their negative attitude towards Javanese language. Based on the calculation, it can be revealed known that $73 \%$ respondents agreed on statements that they try to learn Javanese language properly, and $27 \%$ respondents disagreed to learn language. The result showed that most of the student's respondents had positive attitude towards Javanese language.

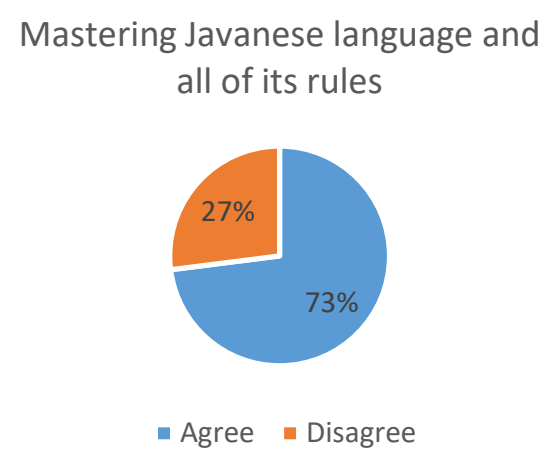

Figure 3 Subjects' responses on Javanese language mastery

Question number three was about whether they mastered Javanese language and its rules or not. This question was associated with the respondents' awareness to the rules of Javanese language as well. Totally, there were 8 respondents agreed that they mastered the 
Javanese language and its rules which was positive attitude, while the 3 respondents disagreed with the question classified as the negative one.

According to the calculation result, it showed $73 \%$ respondents had positive attitude towards Javanese language through their responses on question about their mastery on Javanese language. On the other hand, there were $27 \%$ respondents showed negative attitude. Most of those who showed negative attitude towards the third statement were respondents who used both Javanese language and Bahasa Indonesia as their mother tongue.

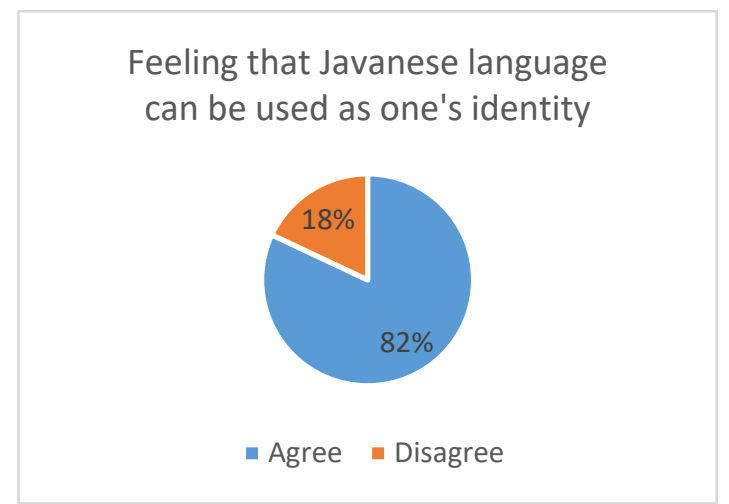

Figure 4 Subjects' responses on Javanese language as identity

Question number four was concerning the participants' feelings that Javanese language can be used as one's identity. It was in the matter of their pride in using Javanese language. In total, there were 9 respondents who agreed for the statement that language can be used as one's identity, while there were 2 respondents showed disagreement. After being calculated based on the intervals, there were $82 \%$ respondents that their whose responses can be classified as positive attitude, while there were $18 \%$ respondents that were whose responses were classified having as negative attitude. Those numbers proved that most of the respondents were proud of Javanese language as part of their identity. The $18 \%$ respondents who showed negative attitude were those who most likely only used Javanese language as their media to communicate with other Javanese speakers. They assumed it did not have any correlation with one's identity.

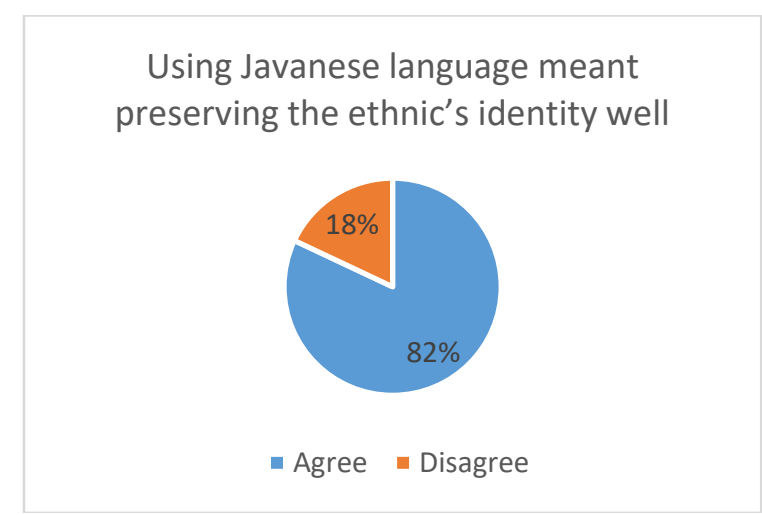

Figure 5 Subject's responses on Javanese language and its preservation 
Question number five was related to using Javanese language as an effort in preserving one's and region's identity. According to the questionnaire result, it showed that 9 respondents agreed for using Javanese language to prove one's and ethnic's identity, although there were 2 respondents stating they disagreed with the question. After being converted into percentage based on intervals, there were $82 \%$ respondents showed positive attitude and $18 \%$ respondents demonstrated the negative one. The calculation result was displayed in the following chart.

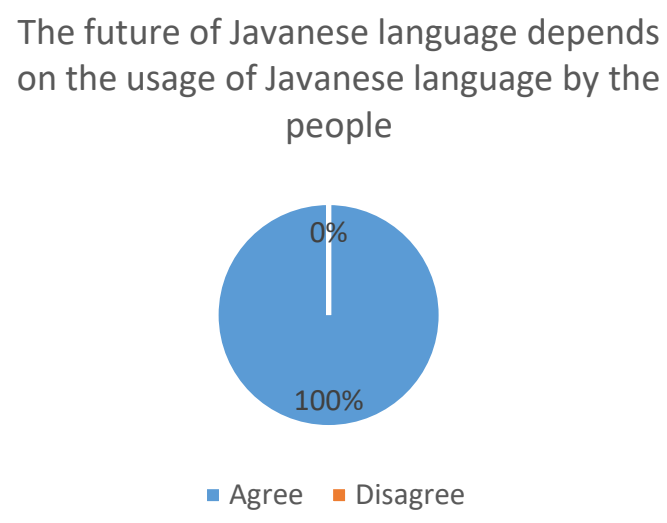

Figure 6 Subjects' responses on the future of Javanese language

Question number six was explaining about the future of Javanese language. Based on the questionnaire result, it showed that all of the respondents agreed with the statement. There were no respondents who disagreed. By this, it can be inferred that the respondents' attitude towards Javanese language was totally positive. It illustrated the subjects' awareness on Javanese language.

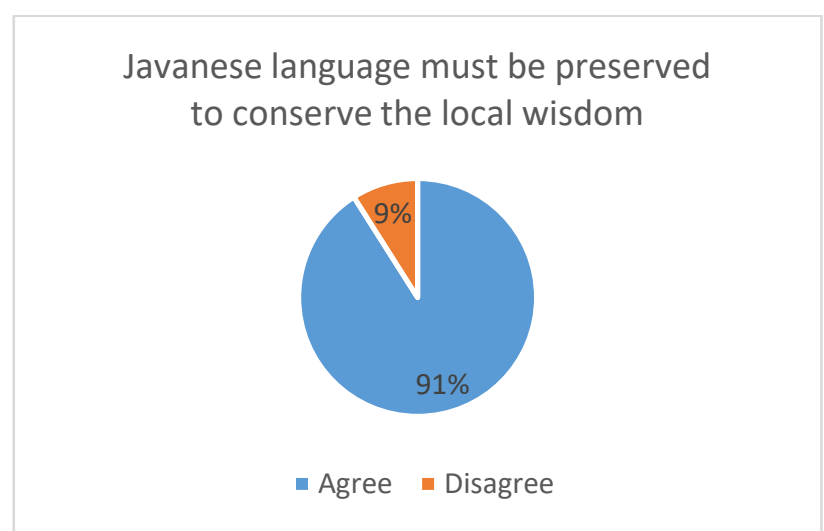

Figure 7 Subjects' responses on Javanese language preservation 
Question number seven was about the correlation between preservation of Javanese language and the local wisdom. There were 10 respondents agreeing with the statement which was included as positive attitude and 1 respondent who disagreed can be classified as negative attitude. The result showed that $91 \%$ respondents stated that they agree if Javanese language must be preserved for the sake of in order to keeping keep it as local wisdom. They realized how important Javanese language to be conserved.

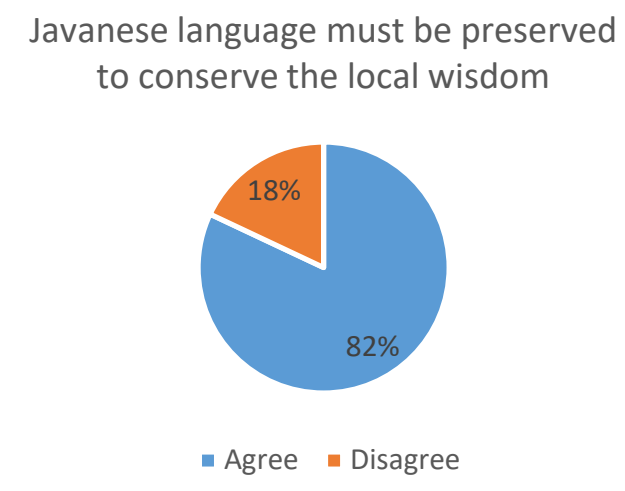

Figure 8 Subjects' responses on Javanese language preservation

Question number eight, was concerns within the respondents' opinion on Javanese language as one of subjects in school. There were 9 respondents who agreed with the statement on number eight, while there the other two were 2 respondents showing showed their negative attitude. After the interval being calculated, the result illustrated showed that that $82 \%$ respondents had positive attitude. They agreed or even had experienced that Javanese language is studied because it is compulsory to be applied obligated in at most of schools in East Java, Central Java, and Special Region of Yogyakarta.

\section{Javanese language is interesting subject to learn at school}

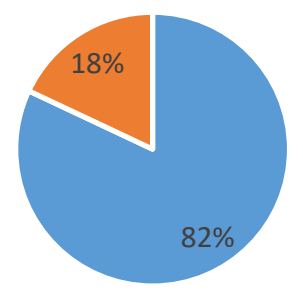

- Agree $\square$ Disagree

Figure 9 Subjects' responses on Javanese language as interesting subject

Question number nine was in connection concerns with how interesting Javanese language was as a subject. There were 9 respondents who agreed with the question and there were 2 respondents who disagreed. It was found out that this question was related to local language teaching at school. For most respondents, the teaching process of local language 


\section{Destyana Cory Prastiti and Emy Sudarwati}

was interesting. So that, therefore, those who agreed was classified as those showing positive attitude, while those disagreed were claimed considered as those a shaving negative attitude.

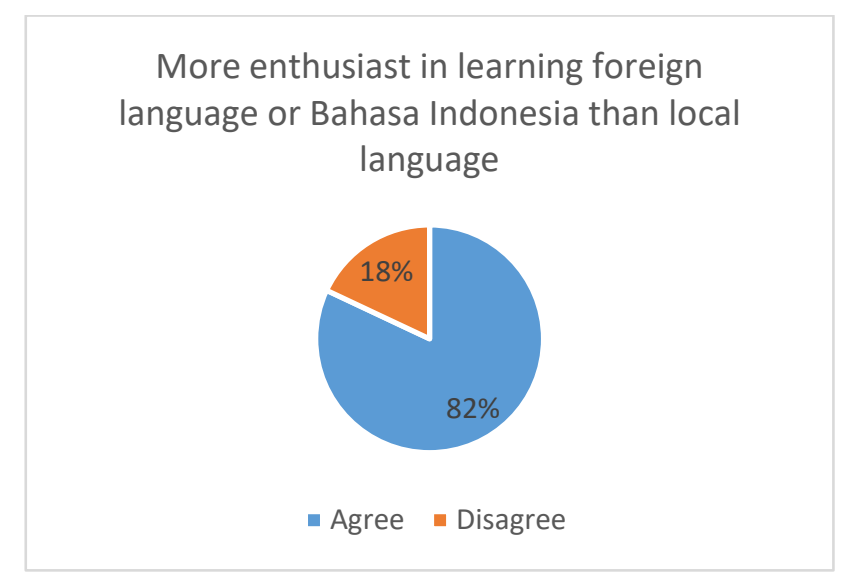

Figure 10 Subjects' responses on local language vs. foreign language

The last question was regarding whether the respondents' enthusiasm in learning local language or the foreign one. It can be known that there were 9 respondents who agreed and they were more motivated to learn foreign language or Bahasa Indonesia. Different from previous explanations that mentioned those who claimed strongly agree or agree can be included as positive attitude, in $10^{\text {th }}$ question, those who said so can be classified as negative attitude.

\subsection{Factors Influencing on the Respondents' Attitude towards the Use of Javanese Language}

Based on the interview result, it was found out that the respondents as Javanese youths showed positive attitude although in some cases, they tend to be negative. For example, when they were asked about the advantages of Javanese language in modern life, it is clearly described in the following excerpt:

"When it is related to the language use in technology and modern life, Javanese language was rarely spoken by its speakers. Otherwise, in its development, Javanese language is still preferred in pop culture products such as in music. Javanese language is mostly used in hip hop songs."

By this referring to that quotation, it can be known that is revealed that the respondent showed positive attitude although he knew that Javanese language had less significant role in modern life. He even revealed a good knowledge on usage of Javanese language in other aspects in terms of culture.

Through the interview process, several factors effecting on how people felt or thought about particular language including Javanese language were found as well. Associating between the interview result and the theory used by Jendra (2010). I, it can be known is revealed that most attitude reflected by the respondents were influenced by various factors. For example, was The quoted in the following excerpt gives further detail: 
"I do not prefer to use Javanese language, because I think it's more difficult than Bahasa Indonesia. When I am at campus, I think it will be more effective to use Bahasa Indonesia. However, I love one part of Javanese language when I was writing aksara Jawa."

The mentioned statement was related to the ease or difficulty level of Javanese language. It can could be classified into the language internal system. The respondent stated that Javanese is more difficult to learn than Bahasa Indonesia, that was why the respondent's attitude tend to be negative although in some cases she also showed positive attitude. Another factor was also showed depicted in the following quotation mentioned by the respondent.

"In my opinion, Javanese language can boost my confidence when talking to elder people due to the use of krama inggil. However, nowadays, not all of the youths can speak in krama inggil althought they can speak Javanese to some extent."

The statement previously stated by the respondent can be considered as the social and traditional factor since the respondent thought the higher variety of Javanese language (krama inggil) can boost her confidence. It was in line with the theory by Jendra (2010).

The last but not least, there was one factor not appearing in the result of the study which is the historical background of nations. During the data collection process, there was no respondents stating any statements related to historical background of particular nations.

\section{DISCUSSION}

\subsection{Javanese Youth's Attitude towards Their Use of Local Language}

As stated by Fasold (1984), expressions of positive feelings towards a language can be defined as positive responses given by the speakers toward particular language. In the first part of questionnaire, the questions given were are related to language and lifestyle, language and impressions for its speakers, language and its specific purposes, language and its benefits as well. By the results on the questionnaire, it can be known is then revealed that most respondents showed positive attitude, although on language and its specific section they thought that Javanese language are less beneficial in business and technology field. cannot be used for business enquiry and technology. This result reached the highest percentage on negative attitude. However, it means that no matter how Javanese language almost has no benefits in modern life, the respondents remained showing positive attitude towards Javanese language. It illustrates that despite of Javanese language limitation in those fields, the respondents still remain showing positive attitude. They still preferred to use Javanese language in some cases because they knew are aware that their ability in Javanese language could improve their confidence. Their opinions on Javanese language benefits did not affect effect on their pride in using the language.

On second part of questionnaire, the statements given were are mostly about the language preference, language preservation and other language policies related to Javanese language. It aims to examine the subjects' pride, efforts and awareness in Javanese language and its norm. By this, the subjects also showed positive attitude towards the statements given although at some statements, some respondents showed negative response. The highest percentage indicated positive attitude reflected on statement "The future of Javanese language depends on the usage of Javanese language by the people". All of participants agreed on this statement, which later are classified as positive attitude later. It can be 


\section{Destyana Cory Prastiti and Emy Sudarwati}

inferred that the respondents were fully aware are fully aware of regarding their roles in maintaining Javanese language. They knew understand that what they did do related to Javanese language would effect on the language existence itself.

\subsection{Factors Influencing on the Attitude of Javanese Youth towards Their Use of Local Language}

The results on the interview process were supported by the results on questionnaire as well. It showed implicated that the factors affecting on the respondents' language attitude towards their use of language was in line with Jendra's theory (2010). He stated that there are four factors that can influence on people's language attitude such as the prestige and power of the language, historical background of nations, the social and traditional aspects in society, and the language internal system. However, in this study, it was only found three factors ranging from the prestige and power of the language, the social and traditional factors, and the language internal system.

According to Jendra (2010), the respondent's statement on the language internal system was related to the ease or difficulty level of a language. It was suitable with the condition of Javanese language due to its since it can be said that it has complex rules for the language use itself. It has three speech levels such as higher (krama inggil), middle (krama madya), and lower variety (ngoko) that is not easy for the speakers or other learners to learn. Those speech levels have different functions in communication as well. By this, those complex rules effect on the respondent's language attitude towards Javanese language.

The second factor appearing in this study was the social and traditional factor. As stated by Jendra (2010: 110), in the society where a diglossic situation is commonly found, the higher variety of the language is normally considered as a better form than the lower one. Through the respondent's quotation on previous sub-chapter, she mentioned that she felt more confident when she could use krama inggil (higher variety of Javanese language). Using krama inggil when talking to older people can help the respondent communicate better with them. It was in line with Jendra's theory (2010), where particular language variety is seen better than other varieties.

Furthermore, the fact that most respondents illustrated positive attitude towards their use of Javanese language also strengthened Jendra's theory on the prestige and power of the language factor which stated that the enthusiasm on learning foreign language is not always correlated with a negative attitude towards the national and cultural feeling of the learners. In this case, although the respondents had studied English for almost 4 years at college, it did not mean that they less appreciated Javanese language as their mother tongue.

The only factor that did not appear in the study was historical background of nations. None of respondents stated any comments related to the history of Indonesia or Javanese as an ethnic language.

Regarding the result of the study, the researchers also compare the overall result of this present study to the previous studies that have been previously reviewed. The results of this present study is are in line with some previous studies conducted by (Hartono, 2013; Wulandari, 2013; Nirmala, 2015; Machmud et al, 2019;) s. Stating that positive attitude on Javanese language will be very beneficial to maintain the existence of Javanese language in 
the long run. This is supported by the result of questionnaires given to the respondents showing that the respondents were fully aware of their roles in maintaining Javanese language so their attitude toward Javanese language will affect the existence of Javanese language in the future. In short, it is clear that the existence of Javanese language will depend very much on how the people using it preserve or maintain the language in their everyday life by making use of the language into parts of their code when communicating. Next, the results of the present research is also in line with the study conducted by Laila (2013) who found out that the Javanese Family moving to Australia still regard their Javanese as their important means of communication and would instill the use of Javanese to their children despite the facts that English is very much dominating as they use English there. The similar case happens to the results of this study showing that these youths are still upholding the positive attitude toward their vernacular namely Javanese language though they have chosen English as their major requiring them to speak using English more yet still most of the respondents show good and positive attitude toward Javanese language as parts of their linguistics repertoire which of course need to be suited with the context where they do communication at that time and by considering other communicative factors affecting them to choose certain codes. The result of this present study is also in line with the previous study by Fitri (2018) stating that the use of certain vernacular in this case Javanese is also affected by the domain where the communication happens. This is because certain domain will determine the choice of linguistics repertoire that one uses. For example, Javanese as the vernacular may not be chosen in the workplace domain as this domain requires more formal use of language so standard language for example Bahasa Indonesia is chosen. This domain consideration may also be linked to language preference which is also affected by setting of the communication resulting in the use of certain linguistics code to be chosen (Laila, 2013).

However, the results of this present study are on the contrary to the study conducted by Setiawan (2013). Setiawan (2013) conducted the research in 3 different locations, which are: (1) A village; (2) A town; (3) A big city in East Java, Indonesia which showed that the Javanese children from a village would still generally use Javanese; those from the town would use both Javanese and Indonesian (the national language); Javanese children from the big city would only use Indonesian. He also found the Javanese children's Indonesian language proficiency tended to be higher compared to their Javanese and their attitudes towards Javanese language were mostly negative. According to Setiawan (2013), the use of Javanese was seen as "a symbol of ethnicity", While those who use Indonesian saw the national language as part of national identity which promoted "effective communication and prestige". Thus, the findings of Setiawan's (2013) is in contrast with this present study in which this study generally showed positive attitudes towards the Javanese language as a vernacular language. The positive attitudes were shown by a group of youth of English department students aged 20-24-year-old, while in Setiawan (2013), negative attitudes were shown by Javanese children aged 9-11-year-old. However, there seemed to be a little bit of similarity on how the respondents from these two studies viewed the vernacular and the national language. Both Javanese children and English department students saw the vernacular language as an important part of ethnicity which had to be kept as their identity. On the other hand, the Javanese children and English department students who preferred to 


\section{Destyana Cory Prastiti and Emy Sudarwati}

use Indonesian (the national language), both agreed on how they perceived the national language as a more effective communication tool since it was spoken universally.

Next, the results of this present study contradicts with Ting and Puah (2010) who conducted a similar research to this present study regarding the language attitude of Hokkien speakers towards Mandarin and their own vernacular language, Hokkien. The respondents of Ting and Puah's (2010) were also university students with an age range of 20 to 25-year-old. They found that the Hokkien speakers held a stronger positive attitude to Mandarin compaapred to Hokkien, even though Hokkien was their vernacular language. They perceived Hokkien as having less leadership skill and less educated than Mandarin. Based on this previous study, there was a big difference in terms of findings where the Hokkien generally showed negative attitudes and viewed the Hokkien speakers as less educated compared with the English department students who still held positive attitudes towards their own vernacular language and also they did not think that the use of one particular vernacular language was a measurement of one's educational level or status, despite the similarity of the respondents' age group in these two studies.

\section{CONCLUSION}

Concerning the result of this research, the 11 respondents showed both positive and negative attitudes towards the use of Javanese language. The positive attitude was largely implied on questions regarding their efforts to conserve Javanese as their local language, while the negative attitude was frequently reflected on several statements associated with their language preference in daily life. It is because they consider their language preference depends on the situation and context they are dealing with. However, their mastery in English since they learned English intensively for more than three years in college does not affect their language attitude towards Javanese as their mother tongue. Their attitude towards Javanese language was mostly affected by several factors such as the Javanese language internal system, social and traditional, and the prestige and the power of language. Further studies may explore more on the topic regarding language attitude of vernacular language other than Javanese to see if the results show the same patterns.

\section{REFERENCES}

Appel, R., \& Muysken, P. (1987). Language Contact and Bilingualism. Amsterdam University Press.

Bailey, B. (2001). The language of multiple identities among Dominican Americans. Journal of Linguistic Anthropology, 10(2), 190-223.

Bucholtz, M. (1999). "Why be normal?": Language and identity practices in a community of nerd girls. Language in Society, 28(2), 203-223.

Bucholtz, M., \& Skapoulli, E. (2009). Youth language at the intersection: From migration to globalization. Pragmatics, 19(1), 1-16.

Crystal, D. (2008). A Dictionary of Linguistics and Phonetics. Blackwell Publishing.

Dornyei, Z. (2007). Research Methods in Applied Linguistics: Quantitative, Qualitative, and Mixed Methodologies. Oxford University Press. 
Eckert, P. (2000). Linguistic Variation as Social Practice: The Linguistic Construction of Identity in Belten High. Blackwell.

Fasold, R. (1984). The Sociolinguistics of Society. Blackwell Publishing.

Fitri, H. L. (2018). Language Attitude of Maindailingnese Teenagers in Desa Sidojadi Kecamatan Bukit Malintang Kabupaten Maindailing Natal. Jurnal Linguistik Terapan Pascasarjana Unimed, 15(2), 125-134.

Hartono. (2013). The Attitude of Young Javanese Learning English towards their Mother Tongue in Relation to the Maintenance of Multilingual Society. CONAPLIN 6 International Conference on Applied Linguistics, 176-183. https://www.researchgate.net/publication/329162589_The_Attitude_of_Young_Javanes e_Learning_English_towards_their_Mother_Tongue_in_Relation_to_the_Maintenance_ of_Multilingual_Society_Keywords_Javanese_language_young_Javanese_learning_Eng lish_language_a

Jendra, M. I. I. (2010). Sociolinguistics: The Study of Societies' Languages. Graha Ilmu.

Laila, A. N. (2013). Language Attitudes and Language Preference of Indonesian-Javanese Teenagers in Melbourne, Australia: A Sociolinguistics View. Medan Bahasa, 7(2), 917.

Machmud, P. A., \& Hastuti, E. (2019). Language attitude of Tegal Javanese dialect maintenance on food stall sellers in Depok, Indonesia. European Journal of Literature, Language and Linguistics Studies, 3(3), 100-107.

Nirmala, D. (2015). Attitudes towards javanese language and its maintenance by the english department students of diponegoro university. International Seminar "Language Maintenance and Shift" $V$.

Nuryani. (2014). Sikap Bahasa Masyarakat Urban terhadap Bahasa Indonesia (Menemukan Tipe Pembelajaran Bahasa Indonesia di Sekolah Wilayah Rural dan Urban ). Konferensi Internasional Linguistik Universitas Airlangga Surabaya.

Pohan, F., \& Butarbutar, R. (2020). Javanese language attitude towards speech levels of vernacular in district of Bandar Selamat Medan. Musamus Journal of Language and Literature, 2(2), 56-70.

Rahmawati, S. (2013). The Javanese people attitude toward Sundanese language. Passage, $1(2), 211-217$.

Rampton, B. (2005). No Crossing: Language and Ethnicity among Adolescents. St. Jerome Publishing.

Seli, S. (2020). No TiLanguage Choice and Attitude in Sumatran-Javanese Intermarriage Families in Relation to Language Maintenance in Lubuklinggautle. JEEL (Journal of English Education, Literature, and Linguistics), 3(1), 116-130.

Setiawan, S. (2013). Children's Language in a Bilingual Community in East Java. The University of Western Australia.

Smith-hefner, N. J. (2007). Youth Language, Gaul Sociability, and the New Indonesian Middle Class. Journal of Linguistic Anthropology, 17(2), 184-203. https://doi.org/10.1525/jlin.2007.17.2.184.184

Subroto, E., Dwirahardjo, M., \& Setiawan, B. (2008). Endangered krama and krama inggil varieties of the Javanese language. Linguistik Indonesia, 26(1), 90-96.

Tabi Manga, J. (2000). Les politiques linguistiques du Cameroun. Editions Karthala. 
Destyana Cory Prastiti and Emy Sudarwati

Tamtomo, K. (2012). Multilingual Youth, Literacy Practices, and Globalization in an Indonesian City: A Preliminary Exploration. Tilburg Papers in Culture Studies, 41.

Ting, S., \& Puah, Y. (2011). Young Hokkien Speakers' Pride in Their Ethnic Language and Mandarin. International Conference on Minority and Majority: Language, Culture and Identity, July.

Wulandari, D. (2013). The importance of positive attitude in maintaining Javanese language. International Seminar on Language Maintenance. 